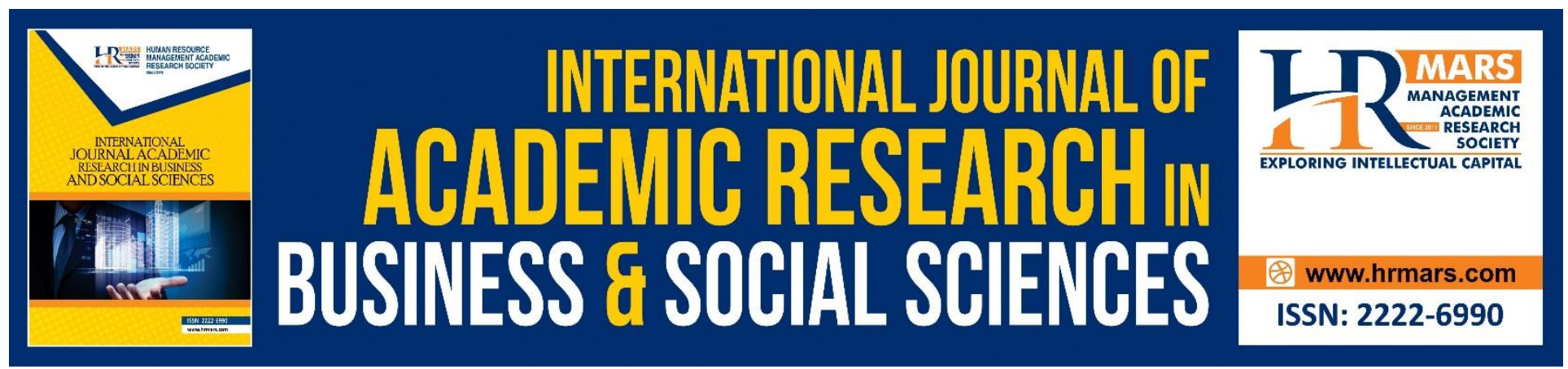

\title{
Religious Appreciation and Psychological Well-Being Among Malaysian Army
} Wan Norhayati Wan Othman, Zaida Nor Zainudin, Muhammad Asyraf Che
Amat, Muhammad Yassin Omar Mokhtar

To Link this Article: http://dx.doi.org/10.6007/IJARBSS/v10-i11/8079

DOI:10.6007/IJARBSS/v10-i11/8079

Received: 07 September 2020, Revised: 29 September 2020, Accepted: 15 October 2020

Published Online: 08 November 2020

In-Text Citation: (Othman, Zainudin, Amat, \& Mokhtar, 2020)

To Cite this Article: Othman, W. N. W., Zainudin, Z. N., Amat, M. A. C., \& Mokhtar, M. Y. O. (2020). Religious Appreciation and Psychological Well-Being Among Malaysian Army. International Journal of Academic Research in Business and Social Sciences. 10(11), 229-243.

Copyright: @ 2020 The Author(s)

Published by Human Resource Management Academic Research Society (www.hrmars.com)

This article is published under the Creative Commons Attribution (CC BY 4.0) license. Anyone may reproduce, distribute, translate and create derivative works of this article (for both commercial and non-commercial purposes), subject to full attribution to the original publication and authors. The full terms of this license may be seen

at: http://creativecommons.org/licences/by/4.0/legalcode

Vol. 10, No. 11, 2020, Pg. 229 - 243

http://hrmars.com/index.php/pages/detail/IJARBSS

JOURNAL HOMEPAGE

Full Terms \& Conditions of access and use can be found at http://hrmars.com/index.php/pages/detail/publication-ethics 


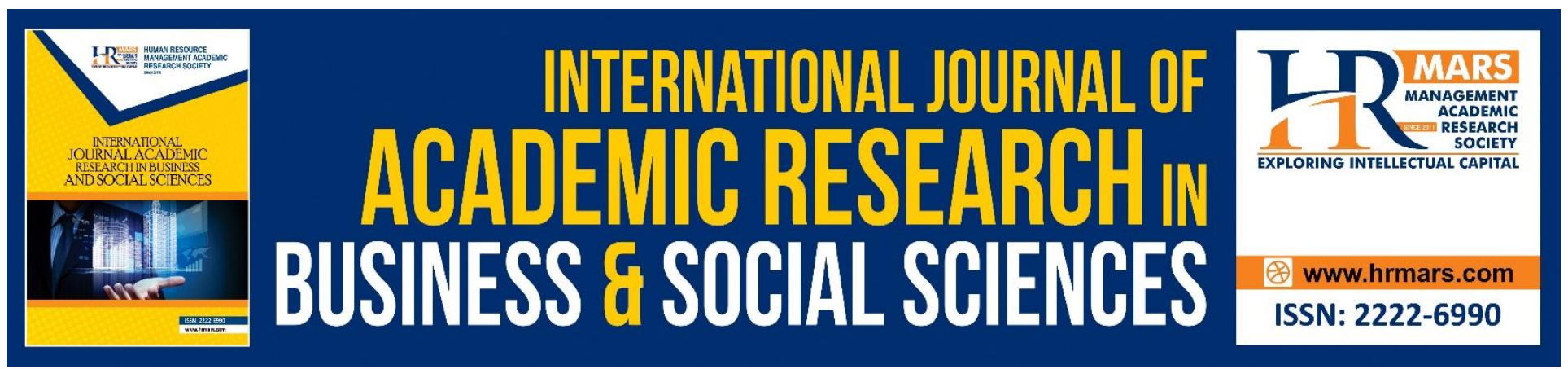

\title{
Religious Appreciation and Psychological Well-Being Among Malaysian Army
}

\author{
${ }^{1}$ Wan Norhayati Wan Othman, ${ }^{1}$ Zaida Nor Zainudin, ${ }^{1}$ Muhammad \\ Asyraf Che Amat, ${ }^{2}$ Muhammad Yassin Omar Mokhtar \\ ${ }^{1}$ Faculty of Educational Studies, Universiti Putra Malaysia, Malaysia, ${ }^{2}$ Research \& Innovation Unit \\ Kolej Universiti Islam Melaka \\ Email:wannorhayati@upm.edu.my
}

\begin{abstract}
The purpose of this study is to analyze the differences in the psychological well-being of Malaysian Army based on demographic factors and to determine the relationship between religious appreciation and psychological well-being of Malaysian Army. The study was conducted using a quantitative method which is a survey study where the questionnaire was distributed to the study samples. The sample of this study is 3,000 Malaysian Army using random group method. The instruments in this study consist of the Religious Appreciation Scale (RAS) and the Psychological Wellbeing Scale (PSWS). The reliability coefficients of these scales using Cronbach's alpha analysis found that over .70. The findings show that no significant difference in the psychological well-being of Malaysian Army based on marriage status variables. While for academic qualification and rank variables show significant differences in psychological well-being. The results of the study also found that the religious appreciation factor had a significant positive relationship with the psychological well-being of Malaysian Army.
\end{abstract}

Keywords: Religious Appreciation, Psychological Well-being

\section{Introduction}

Well-being is a very important and necessary element in the life of human beings. A wellbeing individual is a healthy individual including physically, psychologically and socially healthy. Such individuals will always experience the satisfaction of life and will always be cheerful and happy in their daily lives where their physical condition will be good, their emotions will always be positive indirectly will make their mentality always healthy and well-being (Mahmud, Yusoff, Kadir, \& Ahmad, 2005). A well-being person is also said to be a happy person, without negative feelings such as depression, stress, anxiety and burnout and satisfied with his life. Human well-being from a psychological perspective should be emphasized where it includes cognitive and affective aspects which are positive or negative feelings towards their lives. According to Desa, Ahmad and Sharkawi (2009), psychological well-being is the experience of an individual. It is an individual's assessment of his life that is either in the form of life satisfaction (cognitive assessment) or affective (emotional 
INTERNATIONAL JOURNAL OF ACADEMIC RESEARCH IN BUSINESS AND SOCIAL SCIENCES Vol. 10, No. 11, 2020, E-ISSN: 2222-6990 @ 2020 HRMARS

reaction). Psychological well-being also refers to well-being that is associated or derived from various social, psychological or freedom needs. The implication is in personal growth and depends on subjective assessment of well-being. This shows that human psychological well-being is an important aspect in determining the quality of human life.

National defense is one of the important elements in upholding religion, race and even the country. A well-established country is a country that has a strong and powerful army and sophisticated weapons. The former Prime Minister of Malaysia, Tun Dr. Mahathir Mohamad in his speech at the end of recruit training on 31 December 2001 acknowledged that the Malaysian Armed Forces is a very important organization that is given high trust in defending the country. In order to form a strong and feared army, we should know how to choose a formula that is truly capable of producing efficient and competent army. Aspects of training such as disciplining, training skills using weapons, shaping the morale of members to obey instructions, work hard and not committing any misconduct are something that needs to be highlighted. However war is not only focused on physical strength or technological sophistication alone but involves the psychological state of the army. So towards strengthening the national defense, some important aspects of psychology need to be given attention such as religious appreciation among the defense lineup. Alaudin (2005), in her seminar paper has stated that efforts to strengthen the national defense system should not only focus on physical strengthening and intelligence alone, but also extended to the spiritual aspect. Spiritual strength is the strongest defensive wall that can withstand any threat and attack. As a force centered on 'ad-Din; members of the Malaysian Army cannot separate themselves from recalling the factors of strength and success of past generations. It should be noted that the factor of strength of the ummah in the past is because they have the soul of 'Ruh al-Islam' which radiates the nature of willingness to sacrifice until they finally get martyred. Strong faith in Allah S.W.T. and a solid surrender to Him is a prerequisite to get God's help as Allah says in surah al-Taubah verse 36.

The spirituality of the individual followed by the nature of piety will be able to form a positive or psychology well-being. Every pressure and difficulty will be successfully faced with perseverance and open-mindedness. If we refer to the life history of Rasulullah s.a.w., it turns out that the pressure faced by him and the Muslims is very strong. Logically the shortcomings, especially in the context of armaments, it is impossible for the Muslims to create any success. In terms of member strength, the number of Muslim troops is always small compared to the enemy. For example, the number of troops in the Battle of Badr was 3: 1, in the Battle of Uhud, 4: 1 and in the Battle of Ahzab 4: 1. Yet the absolute belief in the power of Allah s.w.t caused them to remain successful. Indeed, not a single power in the world is capable of fighting Allah s.w.t. Thus during the battle of Badr, Allah s.w.t. recorded his help as in Surah al-Anfal verse 9.

The same situation happened in the battle of Uhud when the strength of 3,000 enemies invaded Medina, the Muslims only numbered about 700 people felt quite depressed. At that time Allah revealed his word, Surah Ali-Imran 12. The companions of the Prophet s.a.w. also faced strong pressure during the Khandak war. An enemy army with 10,000 people surrounded the entire city of Medina has caused Muslims to almost despair (Alaudin, 2005). Allah s.w.t. recorded the event in Surah al-Ahzab: 10

According to Aranda (2008), religious appreciation can prevent individuals from behaving negatively such as risky behaviors, practicing free sex, engaging with drugs and addiction to alcohol and other negative addictions. With that, it can produce people who have good mental health and at the same time will make our country peaceful and well-being. So it is clear here that the appreciation 
INTERNATIONAL JOURNAL OF ACADEMIC RESEARCH IN BUSINESS AND SOCIAL SCIENCES Vol. 10, No. 11, 2020, E-ISSN: 2222-6990 @ 2020 HRMARS

of religion is a very important element in Malaysian Army to ensure that their psychological condition is always good and at the same time make the national defense intact and unharmed. Judging by the figure of 11.3 percent or about 3.3 million Malaysians who suffer from mental illness and 50,000 cases of suicide attempt a year with only 233 psychiatrists throughout Malaysia, as Muslims, the solution to all these problems is to return to Islam completely. Muslims need to do everything that Allah commands, and leave everything that Allah forbids (Harian, 2010).

\section{Research Problems}

Studies on psychological well-being have been extensively conducted in western countries. However, in the context of local studies, there are still few studies on psychological well-being, especially among Malaysian Army. There are several local studies about disciplinary issues (Zahimi, 2011), cases of absenteeism (Shukor, 2011), stress (Zakaria, 2009) and fighting spirit (Basiron, 2008) among members of the Malaysian Army. However, there are still not much studies on the factors that influence psychological well-being of Malaysian Army.

Various social, mental problems and disciplinary decline among Malaysian Army are of great concern to the top management of the Malaysian Army in particular and the community in general. If many members of the military are in such situation, it is worried that the behavior of the members will be detrimental to the country. The string of these problems has also tarnished the credibility of the members of the Malaysian Army and it is one of the social ills that is difficult to eradicate. Among the problems that often occur among members of the Malaysian Army such as mental stress problems, family problems, financial problems, drug abuse problems, long-term leave, early resignation, sharia problems, criminal problems such as robbery, theft and even general disciplinary problems. Based on statistics of social behavior problems and mental stress around 2008 to 2012 shows 15 percent of the Four Divisions, eight percent of the Three Divisions and three percent of the Two Divisions (Malaysian Human Resources Branch, 2013). Among the cases reported involving military personnel are, a father of military member claimed that his son who served at the ATM suffered from mental illness because he was abused while in service until he was admitted to Tanjung Rambutan Mental Hospital and had to divorce his wife and separate with his children (Bernama, 2010).

\section{Research Objective}

The purpose of this study is to:

To analyze the difference of psychological well-being of Malaysian Army based on demographic factors.

To analyze the relationship between the religion appreciation and the psychological well-being of Malaysian Army.

\section{Literature Review}

\section{Definition of Operational Concepts}

\section{Religion Appreciation}

Religion Appreciation or religiosity refers to the religious lifestyle or religious life especially to the religion in the West or in the context of Islam, the appreciation of religion refers to the way of life of particular individual Muslim (Rahman, 2002). Appreciation of religion is defined as the efforts and actions of individuals or groups of people to implement religious teachings in daily life (Mahmood, 
INTERNATIONAL JOURNAL OF ACADEMIC RESEARCH IN BUSINESS AND SOCIAL SCIENCES Vol. 10, No. 11, 2020, E-ISSN: 2222-6990 @ 2020 HRMARS

Yusoff, \& Mastor, 2010). Religiosity or religious life is very important in human life because religiosity has a great influence on behavior, personality (Raba, 2001), emotional peace (Kasan, 2002) human self-confidence (Qardhawi, 1998) and happiness in life (Hamka, 1997). Muslims who practice Islam as ad-din are said to appreciate Islam in their daily lives. Appreciation of religion (quality in religion) is from external factors (extrinsic) that is in the process of socialization or from within the individual himself (intrinsic) that is the sincerity of self to practice it (Allport \& Ross, 1967). Usually the appreciation of religion is in line with the word spiritual (spirituality) which means condition, devotion or quality related to spiritual matters even though the two concepts are different (Turner, Lukoff, Barnhouse, \& Lu, 1995). For this study, religious appreciation is defined as the level to which a person makes his religion as a guide and practices it as a way of life. All things that are commanded to be practiced while the things that are forbidden will be avoid with sincerity instead of coercion from anyone. Measurements made to determine the religious appreciation of the respondents using the Religious Appreciation Scale (2009).

\section{Psychological Well-Being}

According to Ryff (1989), psychological well-being is a dynamic concept that covers the subjective, social and psychological dimensions as well as behavior related to well-being. Whereas according to Ryff and Keyes (1995), psychological well-being is translated as a person's positive assessment of his life or defined as a person's life satisfaction. White (2004) sees psychological well-being as emotional health based on high self-esteem and having positive relationships with others as well as less anxiety, non-depression and non-delinquent behavior.

Whereas according to Ryff (1989), psychological well-being is interpreted as an effort to achieve selfperfection based on the true self-potential which is oriented from the six dimensions that have been expressed in the model namely;

1. Self-Acceptance that is to have a positive attitude towards self, have a positive feeling towards the past, know and accept the advantages and disadvantages of self (Gruenert, 2003).

2. Positive Relationships With Others that is to have a friendly, satisfied and reliable relationship, take care of the welfare of others, be able to intimate. Loving and empathizing as well as understanding, taking and giving reciprocally in human relationships (Gruenert, 2003).

3. Autonomy (Autonomy) that is independent, able to face social stress, self-regulation and selfassessment with their own views (Gruenert, 2003).

4. Environmental Mastery that is efficient in managing the environment they are in, able to control all complex outdoor activities and able to use the opportunities available effectively, also able to own and create a context that suits their own needs and assessments (Gruenert, 2003) .

5. Purpose In Life that is to have a goal in life and lead towards one's own goal, feel life now and then is meaningful, trusting and have a purpose in life (Gruenert, 2003).

6. Personal Growth that is continuous development, open to new experiences, aware of selfpotential, self-improvement and behavioral improvement, change in a way that reflects selfknowledge and effective (Gruenert, 2003).

The World Health Organization (WHO) or the World Health Organization (2003) commented that psychological well-being refers to individuals who are mentally healthy and prosperous and able to maintain harmonious relationships with others, participate in community activities and can contribute to society. The Ministry of Health Malaysia (2005) has defined psychological well-being as an individual's ability to deal with stress, avoid conflict, increase peace of mind, stimulate motivation 
INTERNATIONAL JOURNAL OF ACADEMIC RESEARCH IN BUSINESS AND SOCIAL SCIENCES Vol. 10, No. 11, 2020, E-ISSN: 2222-6990 @ 2020 HRMARS

and increase self-confidence in life. Based on the Islamic perspective, psychological well-being is seen based on the spiritual aspects that reflect the human heart, soul, mental and psychology (Haniff, 2000). In the context of this study, psychological well-being is defined as an assessment or positive state of an individual towards his life whether it is an assessment from his cognitive point of view (life satisfaction) or affective (emotion or emotional state). It is also related to the well-being and mental health of the individual. The Ryff Psychological Wellness Scale was used to measure this construct.

\section{Methodology}

\section{Study Design}

This study was using a quantitative method that is a survey study which the questionnaire was distributed to the samples. The data obtained from this random sample were then analyzed and presented with descriptive statistics and significant tests (Awang, Kumar, Satari \& Kunjambu, 2008).

\section{Location and Sample Study}

The study was conducted in army camps in three divisions in Peninsular Malaysia. Among the divisions are Two Divisions, Three Divisions and Four Divisions. The Army has four Combat Infantry Divisions under the Malaysian Armed Forces Headquarters. The sample for this study was set at 3,000 people.

\section{Research Instruments}

According to research ethics, respondents have the right to know why they were given a questionnaire and why the data is used. Therefore, each respondent is given an informed consent letter to be signed before answering a questionnaire (Cohen \& Swerdik, 2005). The instrument in this study consists of three parts, namely the demographic section, the Religious Appreciation Scale (SPA) and the C section, namely the Ryff's Psychological Well-Being Scale (SKPSR).

\section{Findings}

\section{Psychological Well-Being Differences}

The first objective of this study is to analyze the differences in the psychological well-being of Malaysian Army based on demographic factors, namely marital status, academic qualifications and rank.

Ho1: There is no significant difference in the psychological well-being of members of the Malaysian Army based on marital status.

The marital status of Malaysian Army members is categorized into two, namely married and single. Married Army have more responsibilities and commitments in their lives especially to family, wife and children, compared to single Army who think only of themselves other than their responsibilities at work. So, this hypothesis was built to analyze if there is a significant difference in psychological well-being between the married and single Malaysian Army. To find the answer to this study question, a t-test was done as in Table 1. 
INTERNATIONAL JOURNAL OF ACADEMIC RESEARCH IN BUSINESS AND SOCIAL SCIENCES Vol. 10, No. 11, 2020, E-ISSN: 2222-6990 @ 2020 HRMARS

Table 1

Results of the T-Test analysis of Psychological Well-being Malaysian Army Based on Marital Status ( $\mathrm{N}=3000)$

\begin{tabular}{lllllll}
\hline Status & $\mathrm{N}$ & Mean & $\begin{array}{l}\text { Standard } \\
\text { deviation }\end{array}$ & $\mathrm{df}$ & $t$ & $p$ \\
\hline Married & 1750 & 3.99 & .45 & 2998 & .18 & .06 \\
Single & 1250 & 3.79 & .44 & & & \\
\hline
\end{tabular}

The results of the t test analysis based on Table 1 show that there is no significant psychological wellbeing difference at the significance level of less than .05 for both married and single groups [ $\mathrm{t}$ (2998) $=.18 ; \mathrm{p}>$.05]. The mean score of married Army is higher than the mean score of single Army members who are married 158.13 and the mean score of single Army is 153.27. Thus, the null hypothesis constructed is accepted because there is no significant difference between both married and single groups.

Ho2: There is no significant difference in the psychological well-being of members of the Malaysian Army based on academic qualifications.

Education plays an important role in shaping the personality of an individual. Thus indirectly the level of education will affect the maturity, action and thinking of the individual. This hypothesis was built to identify differences in psychological well-being based on the level of education. The ANOVA test was performed and the results are shown as in Table 2.

Table 2

Results of One-Way Anova Analysis of Psychological Well-Being Differences According to the Academic Qualifications of Malaysian Army

\begin{tabular}{lcrrrr}
\hline Variation & Sum of squares & $\mathrm{df}$ & $\begin{array}{c}\text { Mean } \\
\text { Square }\end{array}$ & $F$ & Sig \\
\hline Between Groups & 2.33 & 3 & 0.78 & 2.78 & $0.040^{*}$ \\
Within Groups & 837.49 & 2996 & 0.28 & & \\
Total & 839.83 & 2999 & & & \\
$*$ * $<0.05$ & & & & &
\end{tabular}

The results of one-way variance analysis (ANOVA) through Table 2 show that there is a significant difference in the significance level of less than .05 between Malaysian Army who graduated SRP / PMR, SPM, STPM and Diploma with psychological well-being $[F(3,2996))=2.78 ; p$ $<.05]$. Therefore, it can be stated that there are significant differences for psychological well-being according to the academic qualifications of members of the Malaysian Army. Thus the null hypothesis constructed is not accepted. The Tukey Post Hoc test was performed to see the difference. The level of education at the SRP level shows a significant difference with the level of education at the STPM level. The other stages do not point differences.

Ho3: There is no significant difference in the psychological well-being of members of the Malaysian Army based on Rank 
INTERNATIONAL JOURNAL OF ACADEMIC RESEARCH IN BUSINESS AND SOCIAL SCIENCES Vol. 10, No. 11, 2020, E-ISSN: 2222-6990 @ 2020 HRMARS

An individual will be proud or feel inferior to the rank and position they have acquired and whether these feelings will affect the individual's state of self. This hypothesis was built to see whether there is a difference in psychological well-being among Malaysian Army based on their ranks. A t-test was performed and the results are shown as in Table 3.

Table 3

T-test Results Psychological Well-Being of Malaysian Army

By Rank ( $\mathrm{N}=3000)$

\begin{tabular}{lllllll}
\hline Rank & $\mathrm{N}$ & Mean & $\begin{array}{l}\text { Standard } \\
\text { Deviation }\end{array}$ & $\mathrm{df}$ & $t$ & $p$ \\
\hline Junior PTT & 1432 & 3.85 & 0.52 & 2998 & 2.11 & $0.03^{*}$ \\
Senior PTT & 1568 & 3.81 & 0.53 & & & \\
\hline$*_{p}<0.05$ & & & & &
\end{tabular}

The results of the $t$ test analysis based on Table 3 shows that there is a significant difference in psychological well-being at the significance level of less than .05 for both groups namely Junior PTT and Senior PTT, $t(2998)=.2 .11, p<0.05$. The mean score from the rank of Junior PTT 3.85 is higher than the mean score of the rank of Senior PTT 3.81. So the null hypothesis is not accepted because there are differences between the two groups namely Junior PTT and Senior PTT.

The summary of the findings for the first objective of this study is that there is no significant difference in the psychological well-being of Malaysian Army based on marriage status variables. While for academic qualification and rank variables show significant differences in psychological wellbeing. For academic qualification variables, Malaysian Army who are educated at STPM level show a higher mean than diploma, SPM and SRP / PMR education. For rank variables, Junior PTT shows a higher mean than Senior PTT.

4.2 The Relationship between Religious Appreciation and Psychological Well-Being

The second objective of this study was to analyze at the relationship between religious appreciation and the psychological well-being of Malaysian Army. To answer the objectives of this study, Pearson Correlation test was performed. Table 4 shows the results of the relationship between religious appreciation and psychological well-being.

Table 4

Relationship between Religious Appreciation and Psychological Well-Being.

\begin{tabular}{lc}
\hline & Psychological Well-Being \\
\hline Religious Appreciation & \multicolumn{1}{c}{$0.05^{* *}$} \\
& \\
\hline$* 0<0.01$ &
\end{tabular}


INTERNATIONAL JOURNAL OF ACADEMIC RESEARCH IN BUSINESS AND SOCIAL SCIENCES Vol. 10, No. 11, 2020, E-ISSN: 2222-6990 @ 2020 HRMARS

From Table 4 it is found that the results of Pearson correlation analysis show that there is a significant positive relationship between psychological well-being and religious appreciation, $r=0.05$, $p<0.01$. This indicates that the higher the appreciation of religion the higher the level of psychological well-being.

\section{Discussions}

Differences of Psychological Well-Being

The first objective of this study was to analyze the differences in the psychological well-being of Malaysian Army based on demographic factors. Apart from psychological factors, the demographic factors of an individual such as education, rank, marital status and place of service also play an important role in looking at the relationship with psychological well-being. Vaez and Laflamme (2002) have done many studies on the relationship between psychological well-being and demographic factors. Based on their study found that demographic factors greatly influence the psychological wellbeing of individuals.

\section{Marital Status}

The results of t-test analysis showed that there were no significant psychological well-being differences for both married and single groups. So, the null hypothesis constructed is accepted because there is no difference between the two groups, namely married and single. This finding is different from the findings of several other studies where the results of the study found that married individuals tend to be more high psychologically well-being compared to single individuals (Kamp Dush \& Amato, 2005; Suhail \& Chudhry, 2004). There are also other studies that show that marriage has a strong and positive relationship on psychological well-being for both women and men (Horwitz, Allan \& Helene, 1998; Simon, 2002; Williams, 2003). Pawar and Rathod (2007) found that a married person has better psychological development than a single person.

According to Pavot and Diener (1993), life satisfaction is positively related to one's marital status. Psychological well-being is translated as a person's positive assessment of his or her life or defined as one's life satisfaction (Ryff \& Keyes, 1995). While Frank and Conte (2004) stated that stress can occur among those who are still single compared to those who are married. The results of the study of Wong, Leong, Ko, and Oi (2001) found that married nurses have better mental health and less depressive symptoms, feelings of inadequacy and social dysfunctions compared to single nurses. This is because married nurses get support from their partner because their own partner helps them overcome problems or work stress. This shows that married individuals have a better psychological condition than single individuals.

\section{Level of Education}

The mean level of education at the STPM level is the highest mean of psychological well-being followed by and the lowest mean is the mean level of education at the SRP / PMR level. For members of other ranks, STPM level is considered as a high level of education because the minimum entry qualification for members of other ranks is at the SRP / PMR level. Based on a study by Lyons and Yilmazer (2005), the results of their study found that education has a positive relationship with psychological well-being based on religious appreciation. When the appreciation of religion is seen as a factor, thus the higher a person's education the higher the psychological well-being of the individual (Banthia, Moskowitz, Acree, \& Folkman, 2007). Based on a study by Zuzanek, Jiri and 
INTERNATIONAL JOURNAL OF ACADEMIC RESEARCH IN BUSINESS AND SOCIAL SCIENCES Vol. 10, No. 11, 2020, E-ISSN: 2222-6990 @ 2020 HRMARS

Manell (2005), workers with a low level of education face more stress than those with higher education. Individuals with a good level of education have high levels of self-control in several situations such as emotional control, work management, job leadership, money acquisition, household management and household tasks.

Other studies have found that good income and education will affect psychological happiness and well-being (Dolan, Peasegoog \& White, 2008; Smith \& Faris, 2005). The results of a local study by Ahmad et.al (2009) show that the level of education, work experience and support from spouses, friends and even neighbors are significantly related and affect subjective well-being among the elderly in Malaysia. Good education is also very important in generating positive social support. This is because education can give individuals access to a number of roles with an independent network that will energize various potentials for more supportive and profitable relationships. Education can also help individuals maintain more meaningful relationships with others in most situations such as problem management, the ability to discuss as well as considerate and cooperative attitudes.

\section{Rank}

The results of the t-test showed that there was a significant difference between the Malaysian Army based on the rank. The rank of Junior PTT which consists of Krafman, Lance Corporal, Corporal, and the rank of Senior PTT namely Sergeant, Sergeant Staff, PW2 and PW1 with psychological wellbeing. The Junior PTT mean is higher compared to the Senior PTT mean. Therefore, it can be concluded that there are significant differences in psychological well-being based on the rank of Malaysian Army. So the constructed hypothesis is not accepted. This is likely because their workload and roles differ according to their respective ranks. Usually when there are mistakes and problems in the workplace, the Senior PTT who will be called and scolded by the officer for not taking good care of his subordinates.

These results are similar to some studies that have been conducted where the results show there is a positive relationship between rank and individual psychological well-being (Ellison, Gay \& Glass, 1989; Suhail \& Chaudhry, 2004). The higher the income and rank, the higher the psychological well-being (Banthia, Moskowitz \& Acree, 2007). Based on a study conducted by Scott (2009) where one of the main causes of stress is due to the status of a person's position. He found that individuals with high positions received less stress than those with low positions.

\section{The Relationship between Religious Appreciation and Psychological Well-Being}

The second objective of this study was to analyze at the relationship between psychological well-being and religious appreciation. The results of the study show positive and significant relationship between psychological well-being and the religion appreciation. The practice and appreciation of religion plays a role in shaping the personality of a human being. Each religion has its own values of belief. Based on the results of Pearson correlation analysis obtained shows that there is a significant positive relationship between psychological well-being and religious appreciation. This indicates that the higher the appreciation of religion, the higher the level of psychological well-being. These results are consistent with the results of a study conducted by Watson and his colleagues where the results of their study show that appreciation of religion contributes to a significant relationship with individual well-being (Diener, 2000; Myers \& Diener, 1995). But the results of this study are contrary to the findings of a study conducted by Nooney and Woodrum (2002) which shows that Christians who have a good appreciation of religion suffer and depression more compared to 
INTERNATIONAL JOURNAL OF ACADEMIC RESEARCH IN BUSINESS AND SOCIAL SCIENCES Vol. 10, No. 11, 2020, E-ISSN: 2222-6990 @ 2020 HRMARS

Christians who have a moderate and open religious appreciation but have positive relationship with social support. This is because those who have a high appreciation of religion will always think and always feel that they have committed many sins causing them to become restless so as to affect their psychological well-being.

Religious appreciation is directly related to mental well-being, life satisfaction (Anson, Anthonovsky \& Sagy, 1990; Levin, Chatters \& Taylor, 1995), low levels of psychological distress (Ellison, Boardman, Williams, \& Jackson, 2001; Levin \& Chatters, 1998), lack of depressive symptoms (Ai, Dunkle, Peterson, \& Bolling, 1998; Garrison, Marks, Lawrence, \& Braun, 2004; Smith, McCullough, \& Poll, 2003) and lack of anxiety (Koening, Moberg, \& Kvale, 1998). Religious appreciation can also reduce the likelihood of anxiety, dependence on alcohol, drugs and dependence on anti-depressant medications (Hill, Angel, Ellison, \& Angel, 2005). There is also other evidence to suggest that there is a link between religious appreciation and depression (Strawbridge, Sherma, Cohen, Robert, \& Kaplan, 1998). Other studies that support the relationship between religious appreciation and depression in some groups (Diener, Tay, \& Mayers, 2011; Ellison C.G, Bradshaw. M, Kuyel, N. \& Marcum, 2011; Fabricatore, Handal, Rubio, \& Gilner, 2004; Fiorito \& Ryan, 2007; Hackney \& Sanders, 2003) and as factors that have a positive impact on psychological well-being (Cohen-Zada \& Sander, 2011; Clarke \& Lelkes, 2009; Helliwell, Layard \& Sachs, 2017). There are also researchers who find that the appreciation of religion has a relationship and psychological well-being can further overcome mental and physical health problems (Homan \& Boyatzis, 2010) and give the individual a more meaningful life (Wnuk, Marcinkowski \& Fobair, 2012). Religious appreciation is also said to have a positive effect on psychological adaptation and less risk of bad behavior (Good \& Willoughby, 2006; Hackney \& Sanders, 2003; Hardy \& Rafaelli, 2003; Sasaki, Kim \& Jun Xu, 2011).

A study conducted by Aranda (2008) on 230 Latino ethnic subjects at the Alta Med Treatment Center aimed to look at the relationship between religious appreciation and mental health. This study is in the form of interviews and the results of the study found that many subjects who are active in religious activities were found to show less symptoms of depression. Reed and Nevile (2013) conducted a study to look at the influence of religious and spiritual appreciation on psychological well-being among 167 black women in the United States. The results of the study found that there is a direct relationship between the two factors, namely religious and spiritual appreciation with the psychological well-being of the black woman. It is also found that spirituality is a mediator between the appreciation of religion and mental health globally and the appreciation of religion with the satisfaction of life.

While the study of Garcia-Alandete and Valero (2013) was done on 180 Spanish people, which are 138 women and 42 men. Their study aimed to look at the relationship between religious appreciation and psychological well-being. The Religious Orientation Scale and Ryff'f Psychological Well-being Scales questionnaires were used in their study. The results of the study found that there is a positive and significant relationship between religious appreciation and the dimension of autonomy. But there is a negative relationship between religious appreciation and the dimensions of self-acceptance and the purpose of life. Maltby, Lewis, and Day (1999) in their study of 474 (251 males and 223 females) students at one of the universities in the United Kingdom looked at the role of religion in the psychological well-being of students in the UK. The results of the study found that there is a relationship between religion and psychological well-being but with the presence of a mediator that is the practice of prayer. There are other studies that have proven that religion plays an important role in dealing with various questions, especially when faced with stress. Religion is also 
INTERNATIONAL JOURNAL OF ACADEMIC RESEARCH IN BUSINESS AND SOCIAL SCIENCES

Vol. 10, No. 11, 2020, E-ISSN: 2222-6990 @ 2020 HRMARS

important in the context of action. This condition has been proven through the study of Pargament et. al. (1999) in which they have proven that prayer and belief in God are the two most popular sources of action. Other sources of action include guidance from the pious and communication with God through prayer ceremonies.

\section{Conclusion}

Psychological well-being is a state of a person who has the ability to accept himself and his life in the past (self-acceptance), personal growth, belief that his life is meaningful and purposeful, positive relationship with others, the ability to manage their life and the environment effectively (environmental mastery), and the ability to determine their own actions (autonomy). Therefore, religious activities and courses to improve the identity of military personnel should be done frequently to military personnel, especially members of the Malaysian Army.

In conclusion, to achieve a high level of psychological well-being, individuals need to be influenced by religious appreciation factors. Therefore, to improve the level of psychological wellbeing of Malaysian Army members, they need to be given adequate training to handle their emotions, deal with stress, solve problems, positive thinking and they should be rewarded for their services to the religion, the nation and the country. It is hoped that this study can benefit not only the Malaysian Army but also counseling practitioners in Malaysia..

\section{Acknowledgement}

This research received no specific grant from any funding agency in the public, commercial or notfor-profit sectors.

\section{Corresponding Author}

Wan Norhayati Wan Othman

Department of Counsellor Education \& Counselling Psychology

Faculty of Educational Studies

Universiti Putra Malaysia

Email:wannorhayati@upm.edu.my

\section{References}

Ai, A. L., Dunckle, R. E., Peterson, C., \& Bolling, S. F. (1998). The Role of Private prayer in psychological recovery among midlife and aged patients following cardiac surgery. Gerentologist, 38, 591601.

Allport, G., \& Ross, J. M. (1967). Personal religious orientation and prejudice. Journal of Personality and Social Psychology, 5, 432-443.

Anson, O., Antonovsky, A., \& Sagy, S. (1990). Religiousity and well-being among retirees: A question of causality. Behavior, Health and Aging, 1, 85-97.

Aranda, M. P. (2008). Relationship between religious involvement and psychological well-being: $A$ Social Justice perspective. Health \& Social Work, 33 p. 9-21

Awang, M. G., Kumar, S., Satari, S. Z., \& Kunjambu, B. (2008). Introduction to Research Methodology For Social Sciences. Pahang: Universiti Malaysia Pahang.

Banthia, R., Moskowitz, J.T., Acree \& Folkman, S. (2007). Socioeconomic differences in the effects of prayer on physical symtomps and quality of life. Journal of Health Psychology, 12, 249-260. 
INTERNATIONAL JOURNAL OF ACADEMIC RESEARCH IN BUSINESS AND SOCIAL SCIENCES

Vol. 10, No. 11, 2020, E-ISSN: 2222-6990 @ 2020 HRMARS

Basiron, K. (2008). Daya Juang Ketenteraan: Hubungannya dengan tekal terhadap organisasi, kepuasan kerja, jiwa tentera dan kepimpinan dalam Tentera Darat Malaysia. Tesis PhD. Universiti Kebangsaan Malaysia, Bangi.

Clark, A. E., \& Lelkes, O. (2009). "Lets us pray: Religious interactions in life satisfaction."(Working paper: Paris School of Economics).

Cohen, R. J., \& Swerdik, M. E. (2005). Psychological Testing and Assessment. An Introduction to Test and Measurement (6th Ed). New York: Mc Graw-Hill.

Cohen-zada, D., \& Sanders, W. (2011). Religious participation versus shopping: What makes People Happier?. The Journal of Law and Economics 54(4):889-906

Diener, E. (2000). Subjective Well-being: The sciences of happiness and a proposal for a national index. American Psychologist, 55, 34-43.

Diener, E., Tay, L.,\& Myers, D. (2011). The religion paradox: If religion makes people happy? A review of the economic literature on the factors associated with subjective well-being. Journal of Economic Psychology, 29(1),94-122

Dolan, P., Peasgood, T., \& White. (2008). Do we really know what makes us happy A review of the economic literature on the factors associated with subjective well-being. Journal of Economic Psychology, Vol. 29, (1), 94-122

Ellison, C. G., Boardman, J. D., Williams, D. R., \& Jackson, J. S. (2001). Religious involvement, stress and mental health: Findings from the 1995 Detroit Area Study. Social Force, 80, 215-249.

Ellison, C. G., Bradshaw, M., Kuyel, N., \& Marcum, J. P. (2011). Attachment to God, Stressful Life Events, and Changes in Psychological Distress. Review of Religious Research 53(4): 493-511

Ellison, C. G., Gay, D. A., \& Glass, T. A. (1989). Does religious commitment contribute to individual life satisfaction?. Social Forces, 68, 100-123.

Fabricatore, A. N., Handal, P. J., Rubio, D. M., \& Gilner, F. H. (2004). Stress, religion and mental health: Religious mediating and moderating roles. International Journal for the Psychology of Religion, 14(2), 91-108.

Fiorito, B., \& Ryan, K. (2007). Spirituality and psychological well-being: A mediator-moderator study. Review of Religious research, 48(4), 341-368.

Frank, J., \& Conte. (2004). Work in 21 century: An introduction to industrial and organizational psychology. USA: Mc Graw Hill.

Garcia-Alandete, J., \& Valero, B. (2013). Relationship between religious orientation and psychological well-being among Spanish undergraduates. Acción Psicológica 10(1):153-161

Garrison, M. E. B., Marks, L. D., Lawrences, F. C., \&Braun, B. (2004). Religious beliefs, faith, community involvement and depression: A study of rural-low income mothers. Women \& Health, 40, 5162.

Good, M., \& Willoughby, T. (2006). The Role of Spirituality Versus Religiousity in Adolescent Psychosocial Adjustment. Journal of Youth and Adolescence, 35(1): 39-53.

Gruenert, S. M. (2003). Intimacy, Fathers, Best Friends \& The Well-being of Young Adult Males. Phd Thesis. Swinburne University Of Technology.

Hackney, C. H., \& Sanders, G. S. (2003). Religiousity and mental health: A meta-analysis of recent studies. Journal for the Scientific Study of Religion, 42(1), 39-53.

Haniff, M. H. (2000). Pandangan umum Islam terhadap kesihatan \& perubatan. Singapura: Perdaus. Hamka. (1997). Tasauf Moden (Edisi Baru). Singapura: Pustaka Nasional PTE LTD. 
INTERNATIONAL JOURNAL OF ACADEMIC RESEARCH IN BUSINESS AND SOCIAL SCIENCES

Vol. 10, No. 11, 2020, E-ISSN: 2222-6990 @ 2020 HRMARS

Hardy, S. A., \& Raffaelli, M. (2003). Adolescent religiosity and sexuality: an investigation of reciprocal influences. Journal of Adolescent, 26(6): 731-739.

Helliwell, J., Layard, R. \& Sachs, J. (2017). World Happiness Report. Wellbeing Research Centre at the University of Oxford.

Hill, T. D., Angel, J. L., Ellison, C. G., \& Angel, R. J. (2005). Religious attendance and mortality: An 8year follow-up of Mexican Americans. Journal of Gerentology, Series B: Psychologuical Sciences and Social Sciences, 60, S102-S109.

Homan, K. J., \& Boyatzis, C. J. (2010). Religiousity, sense of meaning and health behavior in older adults. International Journal for the Psychology of religion, 20(3), 173-186.

Kasan, K. (2002). Kesihatan Jasmani dan Rohani Sebagai Asas Kejayaan Menurut Islam. Universiti Kebangsaan Malaysia: Pusat Pengajian Umum

Koenig, H. G., Moberg, D. O., \& Kvale, J. N. (1998). Religious activities and attitudes of older adults in ageriatric assesment clinic. Journal of American Geriatric Society, 36, 362-374.

Levin, J. S., \& Chatters, L. M. (1998). Religion, health and psychological well-being in older adults: Findings from three national surveys. Journal of Aging and Health, 10, 504-536.

Levin, J. S., Chatters, L. M., \& Taylor, R. J. (1995). Religious effects on health status and life satisfaction among black Americans. Journal of Gerontology, Series B: Psychological Sciences and Social Sciences, 50, S154-S163.

Lyons, A. C., \& Yilmazer, T. (2005). Health and financial strain: Evidence from the survey of con sumer finances. Southern Economic Journal, 71, 873-890.

Mahmod, Y., Yusoff, F., Kadir, N. A. R., \& Ahmad, A. (2005). Tingkahlaku Delinkuens dan hubungannya dengan kemurungan, sokongan sosial dan kesejahteraan di kalangan remaja perempuan di pusat pemulihan di bawah kelolaan Jabatan Kebajikan Masyarakat Malaysia. Jurnal Psikologi Malaysia, 19, 95-111.

Mahmood, Y., Yusoff, F., \& Mastor, K. A. (2010). Analisis multi dimensi spiritualiti, religiousiti dan kesihatan mental dalam kalangan ibu tunggal. Prosiding Konvensyen Kaunseling Kebangsaan. Terengganu: Universiti Malaysia Terengganu.

Maltby, J., Lewis, C. A., Day, L. (1999). Religious orientation and psychological well-being: The role of the frequency of personal prayer. British Journal of Health Psychology, Vol 4, Issue 4, pages 363-378, November 1999.

Myers, D. G., \& Diener, E. (1995). Who is happy? Psychological Science, 6(1), 10-19

Nooney, J., \& Woodrum, E. (2002). Religious coping and church-based social support as predictors of mental health outcomes: Testing a conceptual model. Journal for Study of Religion, 41, 359368.

Pargament, K. I., Cole, B., Vandecreek, L., Belavich, T., Brant, C., \& Perez, L. (1999). The vigil: Religion and the search for control in the hospital waiting room. Journal of Health Psychology, 4,327341.

Pavot, W., \& Diener, E. (1993). Review of the satisfaction with life scale. Psychological Assessment, 52(2), 164-172.

Pawar, A. A., dan Rathod, J. (2007). Occupational stress in naval personnel. Military Journal of Armed Forces India, 63(2): 154-156.

Qardhawi, Y. (1998). Panduan Memahami Syariat. Selangor: Pustaka Ilmi

Ryff, C. D. (1989). Happiness is everything, or is it? Explorations on the meaning of psychological wellbeing. Journal of Personality and Social Psychology, 57, 1069-1081. 
INTERNATIONAL JOURNAL OF ACADEMIC RESEARCH IN BUSINESS AND SOCIAL SCIENCES Vol. 10, No. 11, 2020, E-ISSN: 2222-6990 @ 2020 HRMARS

Ryff, C. D., \& Keyes, C. L. M. (1995). The Structure of Psychological well-being reviseted. Journal of Personality Social Psychology, 69, 719-727.

Shukor, J. S. M. (2011). Kes tidak hadir tanpa cuti (THTC): kajian penerokaan di kalangan anggota Angkatan Tentera Malaysia (ATM) di kawasan Lembah Kelang. Tesis Master: Universiti Utara Malaysia.

Simon, R. W. (2002). Revisiting the Relationships among Gender, Marital Status, and Mental Health. American Journal of Sociology 107(4): 1065-1096

Strawbridge, W. J., Sherma, S. J., Cohen, R. D., Roberts, R. E., \& Kaplan, G. A. (1998). Religiousity buffers effects of some stressors on depression but exacerbates others. Journals of Gerentology, Series B: Psychological Sciences and Social Siences, 53, S118-S126.

Smith, C., \& Faris, R. (2005). Socioeconomic Inequality in the American Religious System: An Update and Assessment. Journal for the Scientific Study of Religion, Vol. 44 (1), pp. 95-104

Smith, T. B., McCullough, M. E., \& Poll, J. (2003). Religiousness and depression: Evidences for a main effect and the moderating influence of stressful life events. Psychological Bulletin, 129, 614636.

Suhail, K., \& Chaudhry, H. R. (2004). Predictors of subjective well-being in an eastern Muslim culture. Journal of Social and Clinical Psychology, 23, 359-376.

Scott, E. (2009). Socioeconomic status and stress-How Your socioeconomic Status Can Cause Stress. Online. Http:/// stress. About.com/od/stresshealth /a/ socioeconomic. Htm.

Turner, R. P., Lukoff, D., Barnhouse, R. T., \& Lu, F. G. (1995). Religious or spiritual problem: A culturally sensitive diagnostic category in the DSM-IV. The Journal of Nervous and Mental Desease, 183, 435-443.

Vaez, M., \& Laflamme, L. (2002). Experienced stress, psychological symptoms, self rated health and academic achievement: A longitudinal study of Swedish university students. Social Behavior and Personality, 36(2), 183-196

Williams, K. (2003). Has the Future of Marriage Arrived? A Contemporary Examination of Gender, Marriage, and Psychological Well-Being. Journal of Health and Social Behavior. 44(December):470-487.

White, L. B. (2004). The psychological well-being and Academic Achievement of Children Raised by Single Parents. Master dissertation. University of Winconsin-Stout.

Wnuk, Marcinkowski \& Fobair. (2012). The Relationship of Purpose in Life and Hope in Shaping Happiness Among Patients with Cancer in Poland. Journal of Psychosocial Oncology, 30(4):461-83

World Health Organization. (2003). The mental Health Context: mental Health Policy and Sevice Guidance Package. Geneva: WHO.

Wong, D., Leong, S., Ko, C., \& Oi, D. (2001). Mental health of Chinese nurses in Hong Kong: The Roles of nurses stresses and coping strategies. On line Journal of Issues in Nursing. 5(2).

Zahimi, Z. A. (2011) Hubungan Disiplin Anggota Tentera Darat Malaysia (TDM) di Kawasan Lembah Klang dengan Faktor Agama. Masters Thesis. Universiti Utara Malaysia.

Zakaria, K. (2009). Hubungan Stress dun Masalah Disiplin di Kalangan Pegawai-Pegawai dan AnggotaAnggota 10 Briged Para. Tesis Sarjana. Universiti Malaya. 